\title{
A NOVEL INTEGRON IN THE GENOME OF ESCHERICHIA COLI ISOLATED FROM INDONESIAN MONITOR LIZARD (VARANUS SPP).
}

\author{
ESTIPUSPITASARI ${ }^{2}$, ANTONIUSSUWANTO ${ }^{12} *$, AMARILAMALIK ${ }^{3}$,AND \\ WALTERERDELEN"
}

\author{
'Dept. of Biology, Faculty of Science and Mathematics and IVC Biotechnology, Bogor, Agricultural \\ University, Bogor, Indonesia; \\ ${ }^{2}$ South East Asian Regional Center for Tropical Biology (SEAMEO - BIOTROP), Bogor: Indonesia \\ ${ }^{3}$ Dept. of Pharmacy, Faculty of Science and Mathematics, University of Indonesia, Jakarta, Indonesia; 'Dept. \\ of Biology, Faculty of Science and Mathematics, Bandung Institute of Technology, Bandung, \\ Indonesia
}

\begin{abstract}
The genotype of antibiotic resistance in natural isolates of Escherichia coli was determined through integron detection and characterization of the associated antibiotic resistance. E. coli SG2 isolated from Varanus salvator of Java demonstrated resistance to spectinomycin $(50 \mathrm{ng} / \mathrm{ml})$ and streptomycin (SOng/ml). Integron detection indicated that eight isolates out of nine $E$. coli isolates possessed a conserved segment of the integron. Amplification of the inserted cassette of the integron in this SG2 isolate yielded a 1-kb DNA fragment. Sequence analyses indicated that this fragment was homologous with aad gene, which confirmed the resistance to spectinomycin/streptomycin. This is the first report on the presence of integron in the $E$. coli isolated from the environment.
\end{abstract}

Key words: Integron / antibiotic resistance / Escherichia coli

\section{INTRODUCTION}

Antibiotic is a substance produced by a microorganism as protection from another microorganism (Madigan et al. 1997). Antibiotics have a specific target site in the cell. For example, in trying to get hold of protein synthesis targeted to 30S ribosom, the presence of tetracycline, spectinomycin and streptomycin results in an invalid codon-anticodon reaction and therefore, the synthesized amino acid is also invalid ( Schumm 1992).

Currently, there is concern on the spread of antibiotic resistance among bacteria. Such dissemination is partly a consequence of the antibiotic-resistant genes mobility which reside in mobile genetic elements such as plasmids, transposons, and integrons (Francia et al. 1999).

Integron is a new type of mobile element which has evolved by a site-specific recombination mechanism. Integrons consist of two conserved segments of DNA separated by a variable region containing one or more genes integrated as cassettes (Levesque et al. 1995). The 5'conserved segment contained in the int gene, which encodes a polypeptide of 337 amino acids, has been shown to be homologous to other members of the integrase family and on the opposite strand, a common promoter region $P 1-P 2$ is directed toward the site of integration. The 3 ' conserved segment contains the $q a c E \& \mid$, suR genes, and an open reading frame (Fig.l).

\footnotetext{
* Corresponding author : e-mail address : asuwanto@indo.net.id 10
} 

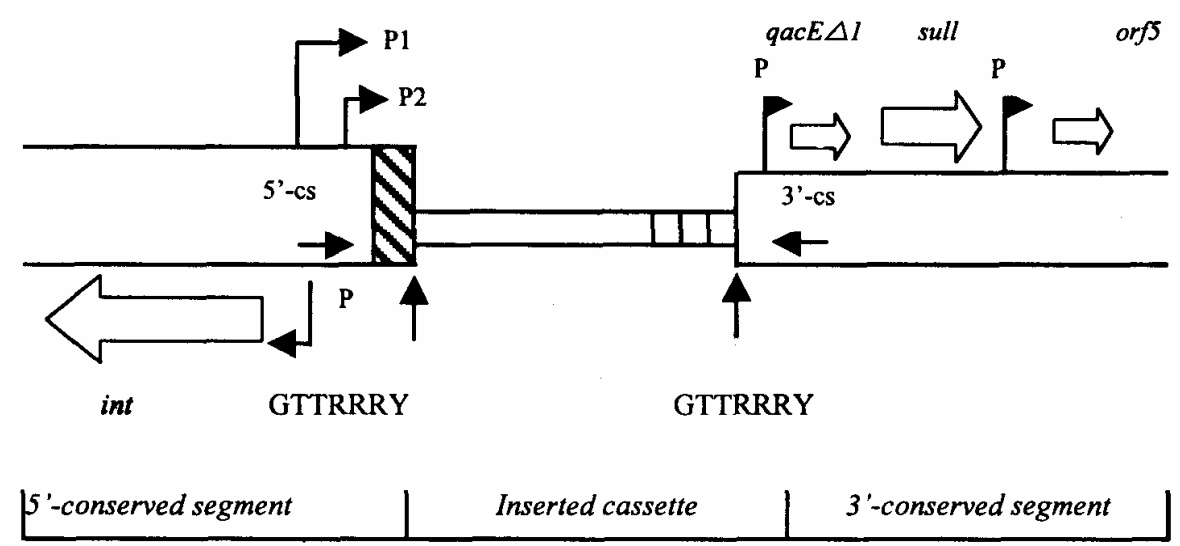

Figure 1. Integron structure (Levesque et al. 1995)

Genetic changes in bacterial genome could contribute to antibiotic resistance in some bacteria. There are three mechanisms of antibiotic inactivation: (i) modification of antibiotic structure; (ii) prevention of antibiotic to get into the target site; or (iii) change in antibiotic target site (Neu 1992).

Resistance to aminoglycoside antibiotics such as spectinomycin and streptomycin, could be due to the penetration failure, the low affinity of antibiotic to ribosom, or the inactivation of the antibiotic by enzymes such as phosphorylase, adenylase and acetylase produced by the bacteria (Gian and Gian 1995).

Desselberger (1998) reported that data on antibiotic-resistant genes in the environment were rare, whereas antibiotic-resistant genes among bacterial strains were increasing at an alarming rate. Biawak monitors (Varanus spp.) are reptilians lacking venomous gland, although there are some reports on Biawak bites resulting in bacterial infection (Auffenberg 1981). Probably, this infection is caused by toxic substances produced by microbiota living in the oral of Varanus spp. Auffenberg (1981) identified five bacteria species that could cause infection. Yogiara (1998) reported that many of $\mathrm{E}$. coli isolates living in the buccal of Varanus spp. are resistant to ampicillin. This study was conducted in order to understand the mechanism of the antibiotic resistance of E. coli in the digestive system of Varanus spp. In this experiment, an antibiotic-resistant gene from E. coli was isolated and further characterized by DNA sequence analysis. 
A novel integron in ther genome of Escherichia coli - Esti Puspitasari et al.

\section{MATERIAL AND MOTHODS}

\section{Bacterial Strains and Plasmids}

The bacterial strains and p;asmids used in this research are shown in Table 1.

Table 1. Bacterial strains plasmida

\begin{tabular}{|c|c|c|}
\hline Bacteria and plasmids & Characteristics & References \\
\hline Escherichia coli TOP 10 & $\begin{array}{l}\text { F mcrA } \Delta(\text { mrr-hsd/RMS-mcr BC) } \phi 80 \text { lacZ } \\
\text { MIS } \Delta \text { lac recAI deoR araD139 } \Delta(\text { ara-leu) } 7697 \\
\text { galU galK rpsL }\left(\mathrm{Str}^{\mathrm{R}}\right) \text { endAI napG }\end{array}$ & $\begin{array}{l}\text { Invitrogen, } \\
\text { Branchburg, } \\
\text { California }\end{array}$ \\
\hline $\begin{array}{l}\text { Escherichia coli isolates } \\
\text { code: } \\
\text { P2;PG1;30.1;5;7;2;SG2;SG } \\
1\end{array}$ & $\begin{array}{l}\text { Wild type (isolated from buccal of Varanus), } \\
A^{R}\end{array}$ & Yogiara 1998 \\
\hline pAS900 & $\begin{array}{l}\text { Generated from pCR@ 2.1-TOPO (Invitrogen, } \\
\text { co). Multiple cloning site one site of EcoRI, } \\
\mathrm{Km} \mathrm{m}^{\mathrm{R}} \text { (Tn5 derivative), } \triangle A \mathrm{Ap}^{\mathrm{R}} \text { with } X m a \mathrm{I} \text { site dan } \\
\text { ScaI site deletions }\end{array}$ & $\begin{array}{l}\text { A. Suwanto } \\
\text { (unpublished) }\end{array}$ \\
\hline pAS901 & $\begin{array}{l}\mathrm{Km}^{\mathrm{R}} ; 11,2-\mathrm{kb} \text { fragment encodes } \mathrm{Ap}^{\mathrm{R}} \text { from } E \text {. } \\
\text { coli } 2-2-E \text { coRI cloned in pAS } 900-E \text { coRI }\end{array}$ & Yogiara 1998 \\
\hline pCRAS & $\begin{array}{l}\mathrm{Km}^{\mathrm{R}} ; 1 \text { 1-kb PCR product from SG2 isolate - } \\
\text { NotI cloned in pAS900-NotI }\end{array}$ & This study \\
\hline $\mathrm{pS} 2 \mathrm{~T}$ & $\begin{array}{l}\mathrm{Ap}^{\mathrm{R}} \text {; 1-kb PCR product from } \mathrm{SG} 2 \text { isolate } \\
\text { cloned in pGEM-T Easy }\end{array}$ & This study \\
\hline pEP10 & $\begin{array}{l}A p^{\mathrm{R}} ; 10-\mathrm{kb} \text { fragment encodes } \mathrm{Ap}^{\mathrm{R}} \text { from } E . \text { coli } \\
2-2-\text { HindIII cloned in pAS900-HindIII }\end{array}$ & This study \\
\hline
\end{tabular}

\section{Growth Conditions}

Antibiotic-resistant bacteria were cultured aerobic (100 rpm) at $37^{\circ} \mathrm{C}$ and kept overnight in Luria Bertani (LB) medium supplemented with one, or a combination of the following antibiotics: ampicillin (100 u.g/ml), streptomycin (50 ng/ml), spectinomycin $(50 \mathrm{ng} / \mathrm{ml})$.

\section{DNA Extraction}

Bacterial isolates were grown in $10 \mathrm{ml} \mathrm{LB}$ in the presence of a selective antibiotic at $37^{\circ} \mathrm{C}$ overnight. Alkaline lysis method (Sambrook et al. 1989) was used for plasmid DNA extraction, and Wizard®Genomic DNA Purification Kit (Promega, Madison, WI) was used according to manufacturer protocol for genomic DNA extraction. 
BIOTROPIA NO. 16, 2001

\section{PCR Amplification}

PCR were performed in Gene Amp ${ }^{\circledR}$ PCR System 2400 (Perkin Elmer, Branchburg, New Jersey). Ready To Go ${ }^{\mathrm{TM}}$ PCR Beads (Pharmacia Biotech, Uppsala, Sweden) was used for each PCR reaction. Each of 25 ul reaction mixtures contained PCR beads, $4 \mathrm{ng} / \mathrm{ul}$ of genomic DNA, $10 \mathrm{ng} / \mathrm{ul}$ of primers (5'cs: GGCATCCAAGCAGCA AG, 3'cs: AAGCAGACTTGACCTGA, qac: ATCGCAATAGTTGGCGAAGT, sul: GCAAGGCGGAAACCCGCGCC) and distilled water up to 25 ul.

PCR condition for the integron was amplified in 35 thermal cycles at $94^{\circ} \mathrm{C}$ for 1 minute, $55^{\circ} \mathrm{C}$ for 1 minute, and $72^{\circ} \mathrm{C}$ for 3 minutes. A final extension step for 7 minutes at $72^{\circ} \mathrm{C}$ was also included. The primers used were $5^{\prime} \mathrm{cs}$ and $33^{\prime} \mathrm{cs}$ that amplify variable regions of integron, qac and sitll primers to amplify the conserved region. PCR product was purified using Gene Clean Kit (Bio 101, La Jolla, California).

\section{Cloning and Transformation}

Amplified DNA was ligated into pAS900 $\left(\mathrm{Km}^{\mathrm{R}}\right)$ and pGEM-T Easy $\left(\mathrm{Ap}^{\mathrm{R}}\right)$ vector. The approximate ratio of pAS900 vector to insert DNA were 1:4 and that of pGEM-T Easy to insert DNA was 1 to 16. Ligation reaction consisted of vectorinsert mixture 1 ul of T4- ligase, Ix ligation buffer, and distilled water up to $20 \mathrm{ul}$. Ligation mixture was incubated at $7^{\circ} \mathrm{C}$ for $16-18 \mathrm{~h}$.

The ligation mixture was transformed into $250 \mathrm{ul}$ of chemically competent $E$. coli TOP10, followed by heat shocked at $42^{\circ} \mathrm{C}$ for 45 seconds. After the addition of $3 \mathrm{ml}$ $\mathrm{LB}$, the culture was incubated with vigorous shaking at $37^{\circ} \mathrm{C}$ for 90 minutes (Sambrook et al. 1989). Transformants were then selected on Luria Bertani Agar (LBA) supplemented with X-gal (40ug/ml) and appropriate antibiotic/s.

\section{DNA Sequencing}

pS2T double - stranded templates were derived from cloning of STI in pGEM-T Easy. Sequencing reaction consisted of 8 ul Big Dye-Terminator, 360 ng of DNA template, $8 \mathrm{ng} / \mathrm{ul}$ of primer and distilled water up to $20 \mathrm{ul}$ Cycle sequencing was performed using PCR machine with three-step profile for 25 cycles: a 10-second denaturation at $96^{\circ} \mathrm{C}$, a 5 -second annealing at $50^{\circ} \mathrm{C}$, and a 4 -minute extension at $60^{\circ} \mathrm{C}$.

Cycle sequencing product was purified by ethanol-sodium acetate precipitation method. A $1.5 \mathrm{ml}$ microcentrifuge tube was filled with 2 ul of sodium acetate $(\mathrm{pH}$ 4.6), $50 \mathrm{ul}$ of ethanol 95\%, and $20 \mathrm{ul}$ of the cycle sequencing mixture, and then incubated at room temperature for 30 minutes. The mixture was centrifuged at maximum speed for 20 minutes. The supernatant was removed from the tube, and 250 ul of $70 \%$ ethanol was added into the tube. The mixture was centrifuged again for 5 minutes. The supernatant was removed and the DNA pellet was vacuum-dried at $50 \mathrm{~cm}$ Hg for 10 minutes. 
A novel integron in the genome of Escherichia coli - Esti Puspitasari et al.

The DNA was electrophoresed according to Sambrook et al. (1989). Prior to electrophoresis, DNA was denatured with 6 ul of loading buffer containing Blue Dextran and $25 \mathrm{mM}$ of EDTA in formamide at $95^{\circ} \mathrm{C}$ for 2 minutes, and quickly placed on ice. Approximately 1.5 ul of DNA sample was loaded to each well and ran for 10 hours. The DNA was compared with those in the GenBank and EMBL databases.

\section{RESULTS AND DISCUSSIONS}

\section{Integron Detection by PCR}

Amplification of DNA sequence experiments using qac-sul primers indicated that there were eight out of nine E.coli isolates possessing 3'- conserved segment of the integron (Table 2). E. coli TOP 10 containing recombinant plasmid pEPIO did not show integron amplification, although it carries a 10-kb DNA fragment originated from genomic DNA of E.coli SG2 isolated from Varanus spp. (Table 1). We suspected that parts of the integron have been deleted when it was digested by restriction enzymes. PCR product using 5'cs-3'cs primers generated a single amplified DNA band of about 1-kb. It was generated from genomic DNA of E. coli SG2 isolate, which was designated as STI (Table 2 and Fig.2 lane 3).

At the downstream end of each resistant gene cassette inserted in the variable region of integrons, there is a short imperfect inverted repeat element called the 59base element. Each inserted gene has its own version of this element (Levesque et al. 1995). The STI was also thought to have a 59-base element, although it was not demonstrated in this study. These 59-base elements are known to be important in the recombination events observed in the evolution of the integron. For example, in plasmid pVSI, which possesses the 5' and 3' conserved segment but no inserted gene between the conserved segments, there is no 59-base element (Levesque et al. 1995).

The other isolates used in this study were found to be similar to pVSI (Table 2). It was reported that pVSI, a plasmid derived from Pseudomonas aeruginosa, possessed integron type $\mathrm{InO}$ which has an unoccupied integration site and hence may be an ancestor of the more complex integrons (Bissonnette and Roy 1992).

Cloning of STI in pAS900 $\left(\mathrm{Km}^{\mathrm{R}}\right)$ vector yielded recombinant plasmid called pCRAS. The purpose of cloning was to detect ampicillin-resistant gene in STI. E. coli TOP 10 harbouring the recombinant plasmid pCRAS was sensitive to ampicillin. This result indicated that STI was not an ampicillin-resistant gene, or it was an ampicillin-resistant gene which could not be expressed.

Expression of antibiotic-resistant genes in the integrated cassettes of integrons depends on cassette position. In all cases, the resistance level was the highest when the gene was present in the first cassette (Collis and Hall 1995). Therefore, there is a need to sequence the STI for gene characterization. 
BIOTROOPIA NO. 15, 2001

Table 2. Integron detection by PCR

\begin{tabular}{lcc}
\hline \multicolumn{1}{c}{ Isolates } & $\begin{array}{c}\text { PCR product using } \\
\text { qac- sul primers }\end{array}$ & $\begin{array}{c}\text { PCR product using } \\
5 \text { 'cs- 3'cs primers }\end{array}$ \\
\hline $\begin{array}{l}\text { PVHAl (control 3'- } \\
\text { conserved segment of } \\
\text { integron) }\end{array}$ & + & - \\
P2 & + & - \\
PEP10 & + & - \\
PGi & + & - \\
30.1 & + & - \\
5 & + & - \\
7 & + & - \\
2 & + & - \\
SG2 & + & + \\
SG1 & + & - \\
\hline
\end{tabular}

$+:$ amplified

- : not amplified

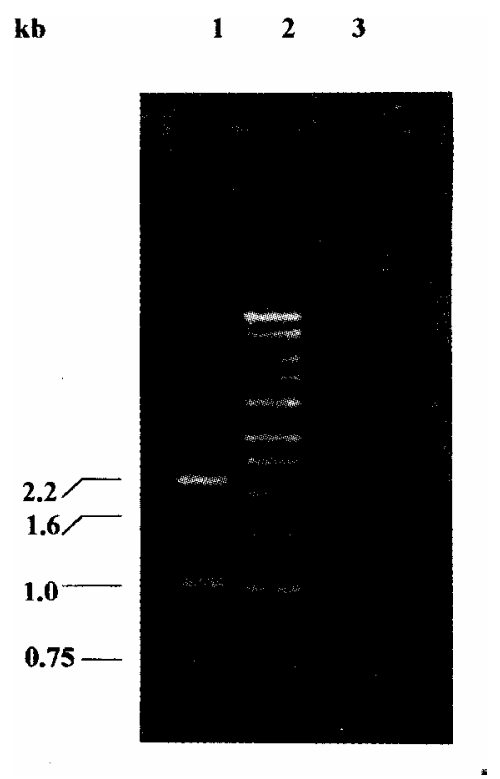

Figure 2. Integron PCR product from total DNA of pVHAl isolate (lane 1), SG2 isolate (lane 3), and $\mathrm{Kb}$ Ladder as marker (lane 2). 


\section{Sequencing}

Cloning of STI in pGEM-T Easy vector yielded recombinant plasmid designated as pS2T. Transformant was isolated, and then sequenced. The result indicated that the STI sequence was homologous to aadA gene encoding aminoglycoside adenyltransferase, which was responsible for streptomycin and spectinomycin resistance in E. coli. BLAST Search analysis of the STI sequence indicated that the 700 nucleotides of 3'STI are integron type 3 (Int 3) as in the IncL/M plasmid from Salmonella typhimurium (96\% identity) and pNCCSOl plasmid from Enterococcus faecalis (96\% identity).

The other 600 nucleotides of 5'STI were similar to the pNCCSOl plasmid from $E$, faecalis (97\% identity) and the R100.1 plasmid from bacteriophage T4 (97\% identity).

In summary, there were eight isolates out of nine $E$. coli isolates possessing a conserved segment of integron and only one possessed inserted gene between the conserved segments of the integron. The sequencing analysis indicated that spectinomycin- and streptomycin-resistant gene was present in the 1-kb DNA fragment.

\section{ACKNOWLEDGMENTS}

This work was supported by DIP project for BIOTROP 1999 / 2000 to Antonius Suwanto. We thank Yeo Chew Chieng from Department of Microbiology, National University of Singapore for conducting DNA sequencing.

\section{REFERENCES}

Auffenberg,W. 1981.The Behavioral Ecology of the Komodo Monitor. University Press of Florida, Florida

Bissonnette, L. and P.H. Roy. 1992. Characterization of InO of Pseudomonas aeruginosa plasmid pVSl, an ancestor of integrons of multiresistance plasmids and transposons of Gram-negative bacteria. J. Bacteriol. 174:1248-1257.

Collis, C.M. and R.M.Hall. 1995. Expression of antibiotic resistance genes in the integrated cassettes of integrons. Antimicrob. Agents. Chemother. 39: 155-162.

Desselberger, U. 1998. Resistance to antibiotics and other antimicrobiol agents. SGM Quarterly. 25:94-95.

Francia, MV., J.C. Zabala, F. Cruz, J.M.G. Lobo. 1999. The Intl integron integrase preferentially binds single-stranded DNA of the attC site. J. Bacteriol. 181: 6844-6849.

Gian, G.S. dan V.H.S.Gian. 1995. Farmakologi dan Terapi: Aminoglikosid. Ed. ke-4. Gaya Baru, Jakarta.

Jacoby, G. 1992. Exploring new strategies to fight drug-resistant microbes. Science. 257:1036-1038.

Levesque, C., L. Piche, C. Larose, and P.H. Roy. 1995. PCR mapping of integrons reveals several novel combinations of resistant genes. Antimicrob. Agents. Chemother. 39:185-191. 
BIOTROPIA NO. 16, 2001

Madigan, M.T., J.M. Martinko, and J. Parker, 1997. Biology of Microorganisms. $8^{\prime \prime 1}$ ed. Prentice Hall, New Jersey.

Neu, H.C. 1992. The crisis in antibiotic resistance. Science. 257:1064-1072.

Sambrook, J., E.K. Frisch, T. Maniatis. 1989. Molecular Cloning, A Laboratory Manual. Ed. ke-2. Cold Spring Harbor Laboratory Press. Cold spring Harbor, USA.

Schumm, D.E. 1992. Intisari Biokimia. Terjemahan Moch. Sadikin. Binarupa Aksara, Jakarta.

Yogiara. 1998. Keragaman genetik isolat Escherichia coli dari rongga mulut biawak (Varanus) dan kloning gen penyandi resistensi ampisilin. Skripsi. Jurusan Biologi FMIPA IPB, Bogor. 